\title{
Analysis of Macroeconomic Indicators on the Farmer Exchange Rate of North Maluku Province: A Case Study of Smallholder Plantation Subsector
}

\author{
Prince Charles Heston Runtunuwu \\ Department of Development Economics, Faculty of Economics and Business, \\ Universitas Khairun, 97719, Ternate, North Maluku Province, Indonesia \\ Corresponding Author: princecharles@unkhair.ac.id
}

\section{ARTICLE INFO}

Publication Info:

Literature Review

How to cite:

Runtunuwu, P. C. H. (2020).

Analysis of Macroeconomic Indicators on the Farmer Exchange Rate of North Maluku Province: A Case Study of Smallholder Plantation Subsector. Society, 8(2), 437-457.

DOI: 10.33019/society.v8i2.235

Copyright $($ C 2020. Owned by Author(s), published by Society

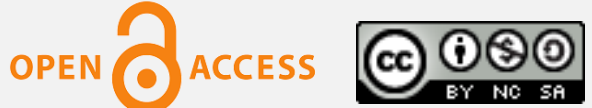

This is an open-access article.

License: Attribution-

NonCommercial-ShareAlike (CC BY-NC-SA)

\section{ABSTRACT}

This study aims to determine the effect of production, land area, and labor on the Farmer Exchange Rate of the smallholder plantation crops subsector individually or partially and the effect of production, land area, and labor simultaneously on the Farmer Exchange Rate in North Maluku Province in 2014 2018. The object of this study was the farmers of North Maluku Province because the agricultural sector plays an important role and contributes greatly to the economy in North Maluku Province. This study was conducted in January-May 2020. The data collected and processed in this study are data within 5 years. The population in this study was all data on the Farmer Exchange Rate, agricultural production, agricultural land area, and labor in North Maluku Province in 2014-2018. The data used in this study were secondary data obtained from the Central Agency on Statistics of North Maluku Province in 2020 and other literature related to this study. The test tool used is multiple linear regression analysis, and the analytical tool used was IBM SPSS Statistics 16.0 software. The results showed that partially production did not affect the Farmer Exchange Rate of smallholder plantation crops in North Maluku province. Partially, land areas affect the Farmer Exchange Rate of smallholder plantation crops in North Maluku province. Individually or partially, the labor did not affect the Farmer Exchange Rate of smallholder plantation crops in North Maluku province. Simultaneously or overall, production, land area, and labor affect the Farmer Exchange Rate of smallholder plantation crops in North Maluku

Copyright $($ 2020. Owned by Author(s), published by Society. This is an open-access article under the CC-BY-NC-SA license. https://doi.org/10.33019/society.v8i2.235 
Received: September 26, 2020;

Accepted: October 16, 2020;

Published: October 26, 2020; province, it can be said that it will affect the farmer welfare.

$\begin{array}{ll}\text { Keywords: } & \text { Agricultural; Farmer Exchange Rate; } \\ & \text { Macroeconomic; Plantation; Smallholder }\end{array}$

\section{Introduction}

The agricultural sector is one of the supporting factors for national development in Indonesia. Agricultural production can be used for the supply of food, feed, industrial raw materials, and exports. Indonesia must be able to develop its manufacturing industry in agriculture by utilizing various Indonesian natural resources through government policies. But in reality, Indonesia has not been able to become a top agricultural producing country at the world level (Istiana, 2018).

The structural transformation of the Indonesian economy towards an industrial style does not automatically eliminate the nuances of economic aggregation. The various classical theory of economic growth and empirical studies of the World Bank showed that the success of industrial sector development in a country is always accompanied by increased productivity and sustainable growth in the agricultural sector. In addition to providing food needs for the population and labor absorption, the agricultural sector is also a supplier of raw materials for the industrial sector and generates foreign exchange (Dumairy, 1997 as cited in Amelia, 2017).

The agricultural sector is one of the dominant sectors in developing countries such as Indonesia, where most of the population has low income and works as farmers, which causes high levels of poverty. According to the Central Agency on Statistics of the Republic of Indonesia (BPS-Statistics Indonesia) in 2019, 129.36 million people are employed and 29.46\% of them work in the agricultural sector. From this data, it can be seen that agriculture has a big contribution. In terms of per capita income, more attention should be paid to the agricultural sector because most of the population works in the agricultural sector, and also the agricultural sector is one of the sectors that contribute greatly to economic growth (Badan Pusat Statistik, 2019).

To increase agricultural productivity, farmers are increasingly dependent on sources from outside their environment. Farmers increase soil fertility by adding fertilizer to agricultural land (Arsyad, 2010). Incentives to agricultural production are mandatory requirements for agricultural development. In this condition, the government plays an important role in providing direction or motivation to farmers in conducting good agricultural practice.

North Maluku is a province in eastern Indonesia. According to the Central Agency on Statistics of North Maluku Province in 2018, the contribution to economic growth in the agricultural sector was $4.13 \%$, while the mining sector was $11.43 \%$. This shows that the role of the agricultural sector has not grown or has not contributed significantly to the economic growth of North Maluku. The government must focus more on increasing the contribution of the agricultural sector in North Maluku (Badan Pusat Statistik Provinsi Maluku Utara, 2019).

Copyright (C) 2020. Owned by Author(s), published by Society. This is an open-access article under the CC-BY-NC-SA license. https://doi.org/10.33019/society.v8i2.235 
Analysis of Macroeconomic Indicators on the Farmer Exchange Rate of North Maluku Province: A Case Study of Smallholder Plantation Subsector

Table 1. Economic Indicators of North Maluku Province 2018

\begin{tabular}{|l|l|r|}
\hline No. & Business Field & Percentage \\
\hline 1. & Agriculture, Forestry, and Fisheries & 4.13 \\
\hline 2. & Mining and Excavation & 11.43 \\
\hline 3. & Processing Industry & 18.22 \\
\hline 4. & Procurement of Electricity and Gas & 3.81 \\
\hline 5. & Water Supply, Waste Management, and Recycling & 5.09 \\
\hline 6. & Construction & 9.05 \\
\hline 7. & Wholesale and Retail Trade; Car and Motorcycle Repair & 8.75 \\
\hline 8. & Transportation and Warehousing & 7.48 \\
\hline 9. & Provision of Accommodation and Food and Beverages & 6.53 \\
\hline 10. & Information and Communication & 6.14 \\
\hline 11. & Financial Services and Insurance & 5.36 \\
\hline 12. & Real Estate & 6.35 \\
\hline 13. & Company Services & 6.06 \\
\hline 14. & Government administration, Defense, and Compulsory Social Security & 6.84 \\
\hline 15. & Education Services & 4.63 \\
\hline 16. & Health Services and Social Activities & 8.04 \\
\hline 17. & Other Services & 9.92 \\
\hline
\end{tabular}

Source: Badan Pusat Statistik Provinsi Maluku Utara (2019)

Most of the population of North Maluku Province in 2014, aged 15 years and over, worked in the agricultural sector 239,450 people (52.5\%). This shows that there must be an optimal role in the development of the agricultural sector in North Maluku. The success in improving the agricultural sector will have a big impact on the people of North Maluku because most of the population work as farmers. However, the opposite is happening, the Farmer Exchange Rate, which is a welfare indicator of the farmer, has decreased and has an impact on farmers' income in North Maluku Province (Badan Pusat Statistik Provinsi Maluku Utara, 2015a).

Supriyati (2005) as cited in Akbar et al, (2019) stated that the decrease in the exchange rate of agricultural production can affect the purchasing power of farmers. On the contrary, the better the exchange rate of agricultural commodities, the better the position of agriculture to industry and a good influence on farmers to increase productivity. Currently, government efforts are needed to make policies to increase the exchange rate of production.

Farmer Exchange Rate (NTP) is one of the indicators used to measure farmer welfare. NTP is the relationship between products sold by farmers and goods and services purchased by farmers. In other words, NTP is a measuring tool for the ability to exchange agricultural goods (products) produced by farmers with goods or services needed for household consumption of farmers and the need to produce agricultural goods (Nirmala et al., 2016).

According to Nirmala et al, (2016), products selling prices and fertilizer prices have a significant effect on the Farmer Exchange Rate of food crops. Meanwhile, production, land area, and pesticides do not have a significant effect on Farmer Exchange Rate. The land area affects the expenses on production factors, the wider the land area, the higher the expenses for

Copyright (C) 2020. Owned by Author(s), published by Society. This is an open-access article under the CC-BY-NC-SA license. https://doi.org/10.33019/society.v8i2.235 
production factors. Likewise, production and pesticides increase farm expenses so that the price index paid exceeds the price index received.

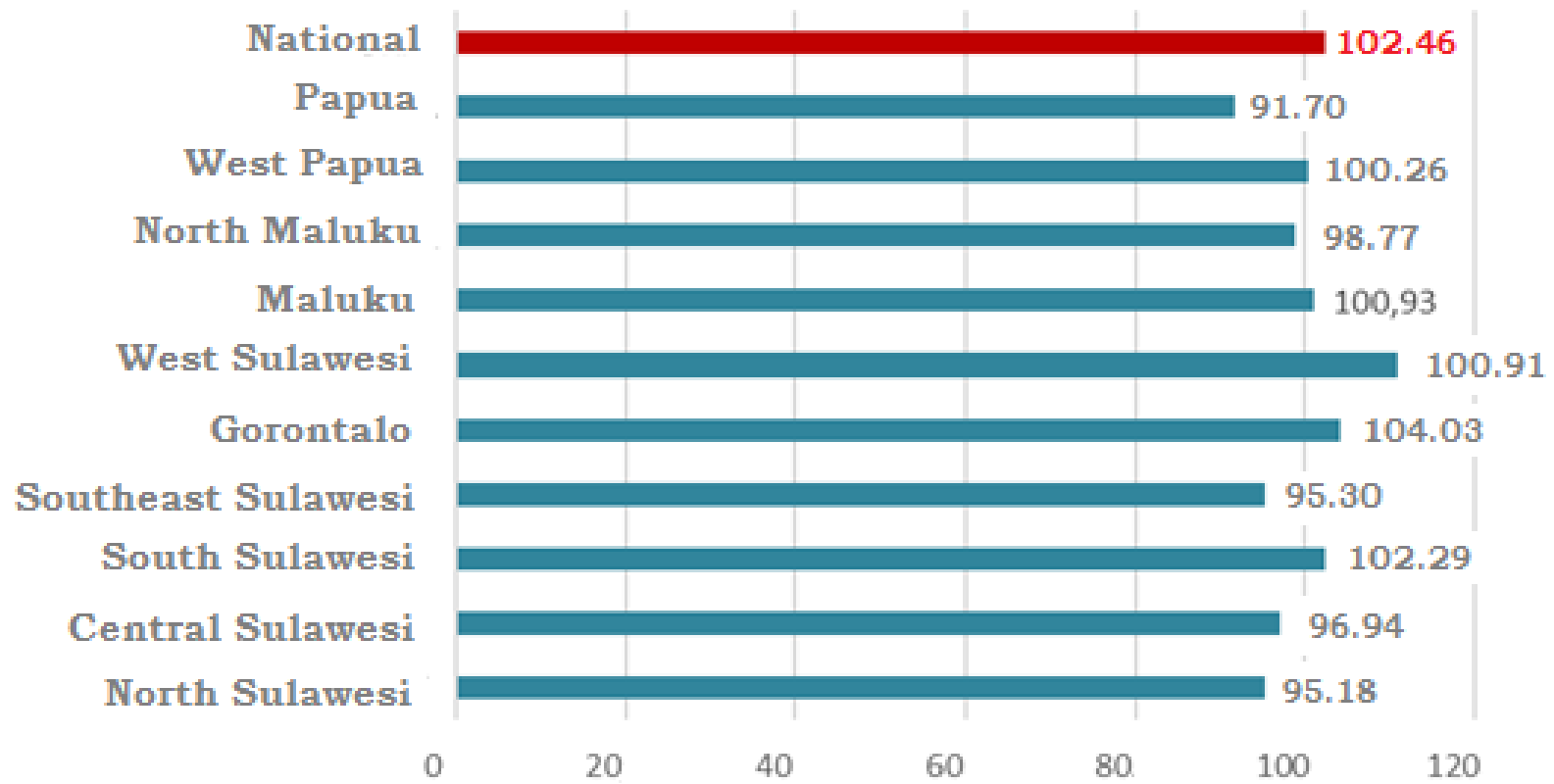

Figure 1. Average Farmer Exchange Rate by Provinces

in Eastern Indonesia in 2018 (2012 = 100)

Source: Badan Pusat Statistik Provinsi Maluku Utara (2018)

According to Istiana (2018), Gross Regional Domestic Product (GRDP) has a significant negative effect on Farmer Exchange Rate. Agricultural productivity has a positive effect on the farmers' welfare, if productivity increases, the farmers' welfare will increase, and if productivity decreases the farmers' welfare also low. The decline in agricultural productivity of food crops is caused by the conversion of agriculturally productive land which causes farmers to experience difficulties in maximizing agricultural production. Based on the regression results of the Farmer Exchange Rate as an indicator measuring farmer welfare on the Consumer Price Index, has a negative effect.

Based on Figure 1, the average Farmer Exchange Rate in Eastern Indonesia showed that North Maluku Province is in fifth place with an average Farmer Exchange Rate of $98.77 \%$ below $100 \%$. This indicates that farmers in North Maluku are in deficit or the farmer's expenses are greater than their income. When compared with Maluku Province which has an average Farmer Exchange Rate of $100.93 \%$ above $100 \%$, which means farmers in Maluku Province are in surplus, better than farmers in North Maluku Province.

The data also shows that government efforts are needed in developing the agricultural sector in North Maluku. Most of the people in North Maluku depend on the agricultural sector for their livelihoods. The government must develop the agricultural sector, for example by providing subsidies for fertilizers, pesticides, etc. to increase agricultural production and increase farmers' income.

Farmers are still selling agricultural raw products to areas that are capable of processing this raw agricultural product, for example, raw copra which is sold to Surabaya and then made

Copyright $($ 2020. Owned by Author(s), published by Society. This is an open-access article under the CC-BY-NC-SA license. https://doi.org/10.33019/society.v8i2.235 
into finished goods such as soap, coconut oil, etc. The agricultural sector which is included in the calculation of the Farmer Exchange Rate of North Maluku Province includes five subsectors, namely the subsector of food crops, horticulture crops, smallholder plantations crops, livestock, and fisheries. However, this study is more focused on smallholder plantations crops.

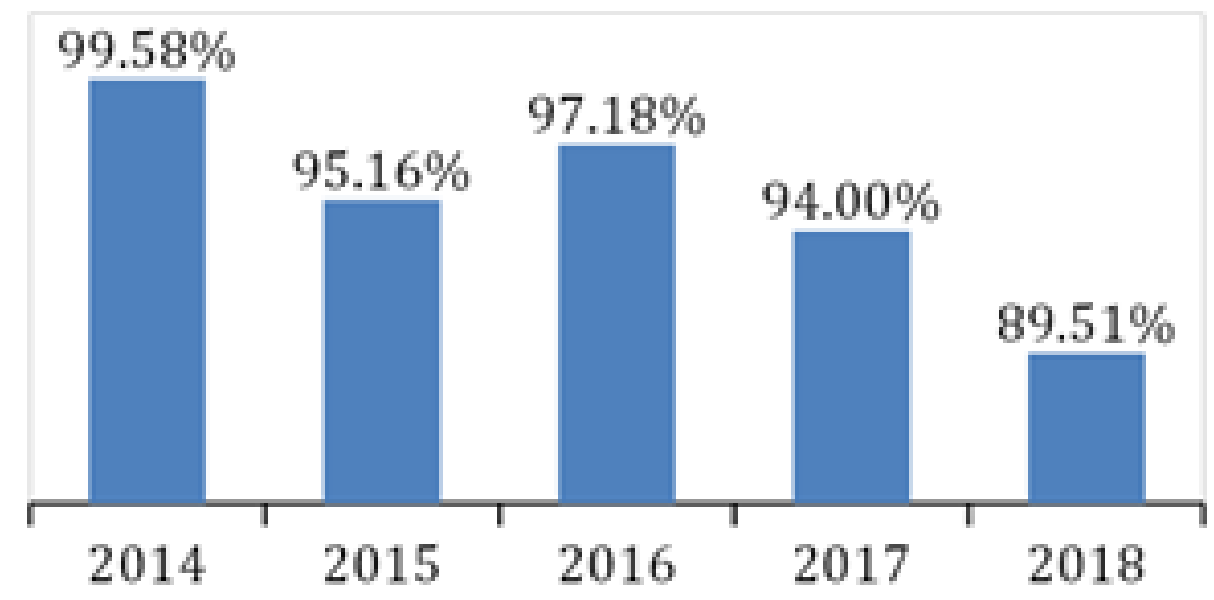

Figure 2. Comparison of the average Farmer Exchange Rate of smallholder plantation crops subsector in North Maluku Province 2014 - 2018 (2012 = 100)

Source: Badan Pusat Statistik Provinsi Maluku Utara (2016); (2018)

Based on Figure 2, the average Farmer Exchange Rate of smallholder plantation crops subsector in 2014 was the highest at $99.58 \%$ and in the following year, the average Farmer Exchange Rate of smallholder plantation crops subsector fell to $95.16 \%$ in 2015 . The situation improved in 2016 where the average Farmer Exchange Rate of smallholder plantation crops subsector increased to $97.18 \%$ but was still below the average Farmer Exchange Rate of smallholder plantation crops subsector in 2014. However, in 2017, the average Farmer Exchange Rate of smallholder plantation crops subsector fell to 94\%. The average Farmer Exchange Rate did not improve in 2018 where the average Farmer Exchange Rate of smallholder plantation crops subsector experienced the worst period in five years, with an average of $89.51 \%$.

Smallholder plantation crops are the main support for the agricultural sector in generating foreign exchange. The main export of agricultural commodities is smallholder plantation products (Dumairy, 2018). Agricultural commodity exchange rates tend to decline every year. This means that a decrease in the exchange rate of agricultural products, or a decrease in the level of agricultural prices relative to the prices of other goods and services, results in a decrease in the real income of farmers (Riyadh, 2015).

Based on Figure 2, the low welfare of farmers who work in the smallholder plantation crops subsector due to the costs incurred is greater than the income received. Sadly, North Maluku Province is highly dependent on the smallholder plantation crops subsector such as nutmeg, cloves, coconut, and others.

Discussion of farmer data that has increased and decreased there are several factors that cause the change, which consist of production factors, land area, and labor numbers, as follows:

Copyright $($ 2020. Owned by Author(s), published by Society. This is an open-access article under the CC-BY-NC-SA license. https://doi.org/10.33019/society.v8i2.235 
Analysis of Macroeconomic Indicators on the Farmer Exchange Rate of North Maluku Province: A Case Study of Smallholder Plantation Subsector

Table 2. Production of Smallholder Plantation Crops in North Maluku Province 2014-2018 (In Ton)

\begin{tabular}{|c|c|c|c|c|c|c|}
\hline \multirow{2}{*}{$\begin{array}{c}\text { Types of Plants } \\
\text { Coconut }\end{array}$} & 232,826 & 231,619 & 230,175 & 225,277 & 225,207 & 229,021 \\
\hline Rubber & 0 & 0 & 0 & 0 & 0 & 0 \\
\hline Cocoa & 13,052 & 12,718 & 12,746 & 9,847 & 10,751 & 11,823 \\
\hline Coffee & 453 & 133 & 0 & 83 & 133 & 160 \\
\hline Cloves & 4.478 & 4.357 & 4.484 & 4.462 & 4.462 & 4.449 \\
\hline Nutmeg & 6,693 & 7,549 & 7,444 & 5,689 & 5,740 & 6,623 \\
\hline Cashew & 1,317 & 2,496 & 2,496 & 2,492 & 2,496 & 2,259 \\
\hline Pepper & 2 & 0 & 0 & 0 & 0 & 0 \\
\hline Vanilla & 60 & 15 & 0 & 0 & 29 & 21 \\
\hline Kapok & 0 & 0 & 0 & 0 & 0 & 0 \\
\hline Sugar Palm & 853 & 573 & 0 & 594 & 594 & 523 \\
\hline Cinnamon & 0 & 29 & 0 & 0 & 0 & 6 \\
\hline Total & 259,734 & 259,489 & 257,345 & 248,444 & 249,412 & 254,885 \\
\hline \hline \% Any Change & & $\mathbf{0} \%$ & $\mathbf{- 1 \%}$ & $\mathbf{- 4 \%}$ & $\mathbf{0 \%}$ & \\
\hline
\end{tabular}

Source: Badan Pusat Statistik Provinsi Maluku Utara (2020)

According to Riyadh (2015), one of the factors affecting Farmer Exchange Rates in North Sumatra is the productivity results which partially or simultaneously has a significant effect on Farmer Exchange Rates. This means that the level of welfare of farmers depends on productivity results.

Based on Table 2, the highest smallholder plantation crop production in 2014 at 259,734 tons, and the average Farmer Exchange Rate based on Figure 2 was also the highest in 2014 at $99.58 \%$. Although it cannot be said to be a good indication because smallholder plantation crops production in North Maluku has decreased for the following years, especially in 2017 at 248,444 tons.

The dominant type of smallholder plantation crop in North Maluku Province is coconut with average production at 229,021 tons a year, and the largest production of coconut in 2014 at 232,826 tons, and the lowest production was in 2018 at 225,207 tons. Then, smallholder plantation crops with high production in North Maluku Province are cocoa with average production at 11,823 tons a year, nutmeg with average production at 6,623 tons a year, cloves with average production at 4,449 tons a year, and the lowest production of smallholder plantations is cinnamon with average production at 6 tons a year.

Production can only be done by a process that involves many inputs (factors of production), in mathematical language, production is determined by the physical relationship between the inputs used and the outputs produced (Retnandari, 2014). Not only land but production factors also affect farmers.

Table 3. Smallholder Plantation Areas in North Maluku Province 2014-2018 (In Hectare)

\begin{tabular}{|c|c|c|c|c|c|c|}
\hline Types of Plants & 2014 & 2015 & 2016 & 2017 & 2018 & Average \\
\hline Coconut & 216,053 & 209,733 & 215,583 & 207,141 & 202,131 & 210,128 \\
\hline
\end{tabular}

Copyright (C) 2020. Owned by Author(s), published by Society. This is an open-access article under the CC-BY-NC-SA license. https://doi.org/10.33019/society.v8i2.235 
Analysis of Macroeconomic Indicators on the Farmer Exchange Rate of North Maluku Province: A Case Study of Smallholder Plantation Subsector

\begin{tabular}{|c|c|c|c|c|c|c|}
\hline $\begin{array}{c}\text { Types of Plants } \\
\text { Rubber }\end{array}$ & $\mathbf{2 0 1 4}$ & $\mathbf{2 0 1 5}$ & $\mathbf{2 0 1 6}$ & $\mathbf{2 0 1 7}$ & $\mathbf{2 0 1 8}$ & Average \\
\hline Cocoa & 34,809 & 32,598 & 32,594 & 32,552 & 29,571 & $\mathbf{3 2 , 4 2 5}$ \\
\hline Coffee & 2,200 & 1,623 & 690 & 1,717 & 1,091 & $\mathbf{1 , 4 6 4}$ \\
\hline Cloves & 21,003 & 22,228 & 20,732 & 21,144 & 21,817 & $\mathbf{2 1 , 3 8 5}$ \\
\hline Nutmeg & 41,509 & 42672 & 44,664 & 40,113 & 42,304 & $\mathbf{4 2 , 2 5 2}$ \\
\hline Cashew & 5,761 & 6,055 & 6,003 & 6,006 & 5,003 & $\mathbf{5 , 7 6 6}$ \\
\hline Pepper & 6 & 26 & 0 & 2,496 & 0 & $\mathbf{5 0 6}$ \\
\hline Vanilla & 488 & 93 & 0 & 0 & 99 & $\mathbf{1 3 6}$ \\
\hline Kapok & 0 & 0 & 0 & 0 & 0 & $\mathbf{0}$ \\
\hline Sugar Palm & 2,221 & 2,126 & 2,126 & 2,126 & 2,126 & $\mathbf{2 , 1 4 5}$ \\
\hline Cinnamon & 0 & 90 & 0 & 0 & 0 & $\mathbf{1 8}$ \\
\hline Total & 324,050 & 317,244 & 322,392 & 313,295 & 304,142 & $\mathbf{3 1 6 , 2 2 5}$ \\
\hline \hline \% Any Change & & $\mathbf{- 2} \%$ & $\mathbf{2} \%$ & $-\mathbf{3} \%$ & $\mathbf{- 3 \%}$ & \\
\hline
\end{tabular}

Source: Badan Pusat Statistik Provinsi Maluku Utara (2020)

According to Ginting et al, (2013), one of the factors affecting the exchange rate of cassava farmers simultaneously and partially is the area of land. The average exchange rate of cassava farmers in North Sumatra was $101.43 \%$. This shows that on average, cassava farmers in North Sumatra are experiencing a surplus in carrying out agricultural activities.

Based on Table 3, the largest area of smallholder plantations occurred in 2014 with a total area of 324,050 hectares. This is following the smallholder plantation production data (see Table 2) which shows that the highest production occurred in 2014 at 259,734 tons. Not only production but the highest Farmer Exchange Rate at $99.58 \%$ but still below $100 \%$, it means the farmer of North Maluku Province have a deficit. The smallest smallholder plantation area occurred in 2018 with a total area of 304,142 hectares.

The type of plant that has the largest land area in North Maluku Province is coconut with an average area of 210,128 hectares a year, and the largest coconut land area in 2014 was 216,053 hectares and the smallest land area in 2017 was 207,141 hectares. Besides, smallholder plantations which have large areas of land in North Maluku Province are nutmeg with an average area of 42,252 hectares a year, cocoa with an average area of 32,425 hectares a year, cloves with an average area of 21,385 hectares a year and the lowest land area for smallholder plantation crops is cinnamon with an average area of 18 hectares a year.

According to FAO as cited in Arsyad (1989), land comprises the physical environment, including climate, relief, soils, hydrology, and vegetation, to the extent that these influence potential for land use. It includes the results of past and present human activity, e.g. reclamation from the sea, vegetation clearance, and also adverse results, e.g. soil salinization. Apart from production and land area, labor is another factor that affects Farmer Exchange Rate.

Copyright (C) 2020. Owned by Author(s), published by Society. This is an open-access article under the CC-BY-NC-SA license. https://doi.org/10.33019/society.v8i2.235 


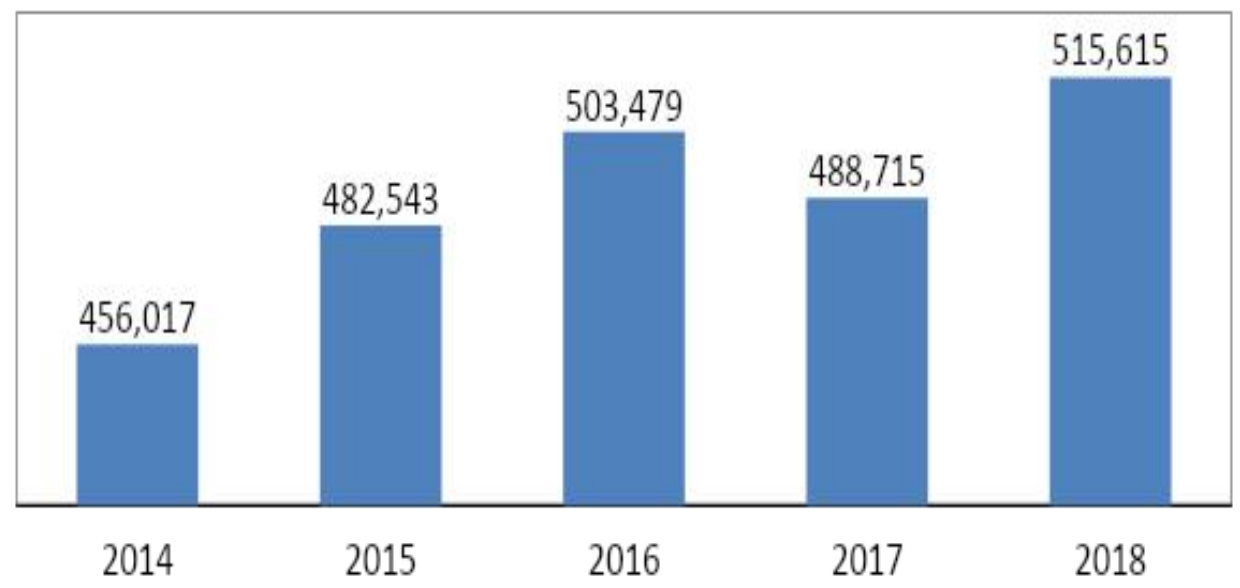

Figure 3. Data on the number of people employed in North Maluku Province Source: Badan Pusat Statistik Provinsi Maluku Utara (2020)

Based on Figure 3, the number of working people in 2018 with a total of 515,615 people, and the lowest was in 2014, with a total of 456,017 people. However, based on Figure 2 (Farmer Exchange Rate of smallholder plantation crops) and Table 2 (production of smallholder plantation crops), this subsector was also the highest in 2014. Workers are individuals who offer skills and abilities to produce goods or services so that companies can obtain benefits and the individual will get a salary or wage according to their expertise (Sumarni \& Soeprianto, 2014).

This study aims to determine the effect of production, land area, labor, and production simultaneously on the Exchange Rate of smallholder plantation crops in North Maluku.

\section{Literature Review}

\subsection{Farmer Exchange Rate}

Conceptually, Farmer Exchange Rate is a measure of the ability to exchange agricultural goods (products) produced by farmers for goods or services needed for household consumption of farmers and to produce agricultural products (Badan Pusat Statistik Provinsi Maluku Utara, 2015b). According to Simatupang \& Maulana (2008) as cited in Nirmala et al, (2016), there are practically no welfare markers for farmer households so the Farmer Exchange Rate is the only option for agricultural development observers in assessing the level of welfare of farmers. The Farmer Exchange Rate is a proxy indicator of farmer welfare.

In general, the definition of Farmer Exchange Rate (Indonesian: Nilai Tukar Petani or NTP) is of three types (Badan Pusat Statistik Provinsi Maluku Utara, 2015b), consisting of:

1. NTP $>100$, it means that the farmers are in surplus. Production price increased more than the increase in consumer prices. In this case, the farmer's income increases more than the expenses. This condition illustrates that the level of farmer welfare is better compared to the level of farmer welfare in the base year.

2. $\mathrm{NTP}=100$, it means that the farmers break even. In this case, the increase/decrease in product prices is the same as the percentage increase/decrease in the price of consumer goods. This condition illustrates that the level of farmer welfare has not changed.

3. NTP $<100$, it means that the farmer is in deficit. In this case, the increase in production prices is relatively smaller than the increase in the price of consumer goods. This condition

Copyright (C) 2020. Owned by Author(s), published by Society. This is an open-access article under the CC-BY-NC-SA license. https://doi.org/10.33019/society.v8i2.235 
illustrates that the level of farmer welfare in a period decreased compared to the level of farmer welfare in the base year.

The uses and benefits of Farmer Exchange Rate include:

1) From the price received index, it can be seen that the fluctuation of the prices of goods produced by farmers. This index is also used as supporting data in calculating agricultural sector income.

2) From the household consumption group, in the price paid index by farmers, it can be used to see fluctuations in the price of goods consumed by farmers, which are the largest part of rural society.

3) Farmer Exchange Rate is used to measure the ability to exchange products sold by farmers for products needed by farmers for production and household consumption. This is noticeable when compared with the exchange rate in the base year. Thus, the Farmer Exchange Rate can be used as one of the indicators in assessing the welfare level of farmers.

According to Ginting et al, (2013), Farmer Exchange Rate has several uses, including as supporting data in calculating agricultural sector income, describe the development of the inflation in rural areas, measure the ability to exchange (term of trade) products sold by farmers with products needed by farmers in production and household consumption. From the Farmer Exchange Rate figures, it can be obtained an overview of the development of farmer income levels in each period, which can be used as a basis for policies to increase the level of farmer welfare, and indicate the level of competitiveness of agricultural products compared to other products.

\subsection{Production}

Production is a routine activity and is beneficial for the prosperity of the nation. Following the Physiocrat, John Stuart Mill, production activity is the center of economic activity, which makes something from nature artificial. In this production process, humans and nature work together. Farmers work with all their knowledge and skills working in agriculture to produce agricultural products (Dua, 2008).

Production is the process of converting inputs into other goods or services with a higher value. Production analysis can be done in the short and long term. In the economic concept, to produce goods in the short term, producers need two kinds of input consisting of fixed input and variable input. Meanwhile, in the long term, there is only variable input. Thus, in the long or short term economic concept, it is not related to the concept of time but with the concept of the existing or not of fixed input (Retnandari, 2014).

The definition of a production function is a production function which is a schedule (or table, or, mathematical equation) that shows the maximum amount of output that can be produced with each group input particular, keeping in mind existing technology (Winardi, 1992).

The production function is a term for the relationship between physical inputs and a firm's physical output. If a small company produces 100 pieces of wood per 8 hours, then the production function consists of the minimum amount of wood, adhesives, varnish, hours of work, machinery, workspace, electricity, etc. required for the production of 100 chairs. In other

Copyright (C) 2020. Owned by Author(s), published by Society. This is an open-access article under the CC-BY-NC-SA license. https://doi.org/10.33019/society.v8i2.235 
words, the factory production function consists of the maximum number of chairs that can be produced with the amount of wood, varnish, and so on (Winardi, 1992).

The focus of this study is limited to production under conditions of "variable proportions". The ratio of the number of inputs can be changed, therefore the employer determines not only the level of output it wants to produce but also the optimal proportion with which inputs will combine (Winardi, 1992).

There are two different ways to state the principle of variable proportion, 1) the variable proportion production means that output can be changed in the short term by changing the number of variable inputs used along with fixed inputs. Of course, when some inputs are changed while others remain constant then the ratio changes. 2) If the variable proportion production experiences, then the same output can be produced with various input combinations with different input ratio variations. This only applies to the long term but is relevant for the short term, where there is more than one input variable (Winardi, 1992).

\subsection{Land Area}

According to FAO as cited in Arsyad (1989), land comprises the physical environment, including climate, relief, soils, hydrology, and vegetation, to the extent that these influence potential for land use. It includes the results of past and present human activity, e.g. reclamation from the sea, vegetation clearance, and also adverse results, e.g. soil salinization. Apart from production and land area, labor is another factor that affects Farmer Exchange Rate.

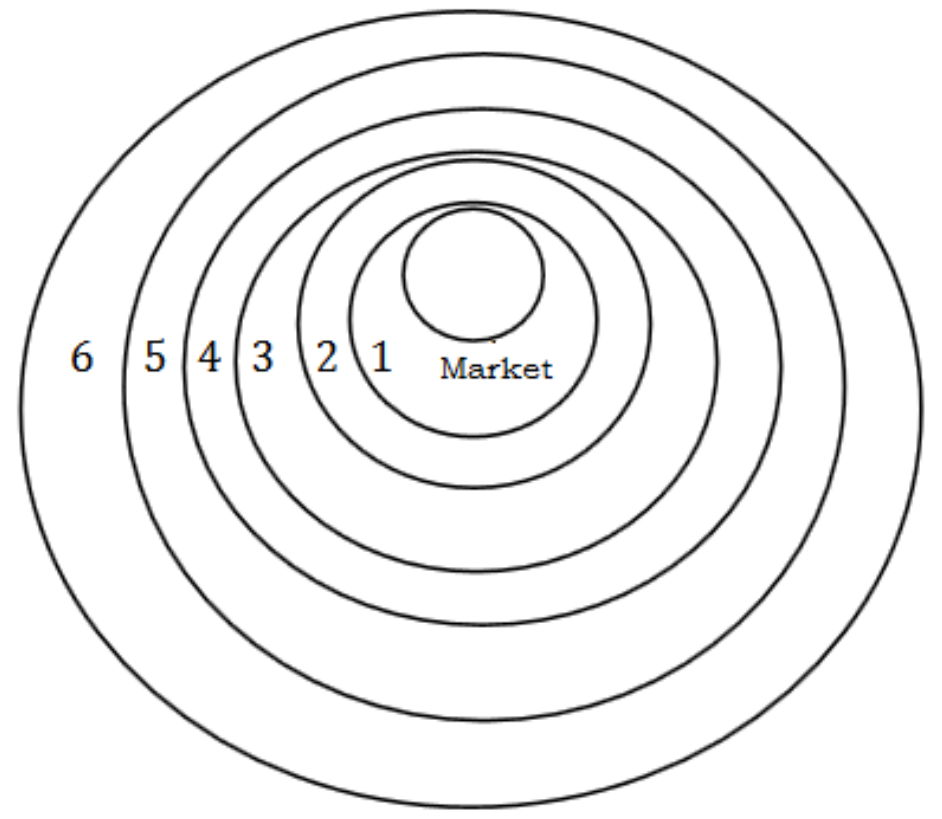

Information:

Ring 1 : Industrial/Craft Center

Ring 2 : Intensive Farming (milk and vegetable production)

Ring 3 : Forest Territory (producer of firewood)

Ring 4 : Extensive Farming

Ring 5 : Livestock Area

Ring 6 : Area of Waste Disposal

Figure 4. Ring Diagram of Von Thünen

Source: Tarigan (2015)

Based on the Von Thünen concept, land rent greatly affects the types of activities that take place in certain locations and encourages the concentration of certain activities in certain locations (Tarigan, 2015). Based on the Von Thünen ring diagram, the smallholder crops plantations consist of types of plants such as coconut, cocoa, nutmeg, cloves, and others which usually use large land areas and only require a little labor can be categorized in ring 4 .

Copyright $\odot$ 2020. Owned by Author(s), published by Society. This is an open-access article under the CC-BY-NC-SA license. https://doi.org/10.33019/society.v8i2.235 
Plantation crops, whether one-year-old or more, are generally monoculture, meaning only one harvest per year, for example, sugar cane plantations, bananas, rubber, cocoa, coconut, tea, cloves, and others. Maintenance is very simple and requires little labor, as weeding is done twice per year and continued with fertilization (Yudono, 2018).

Plantation crops such as cocoa, coconut, coffee, and rubber can maintain their productivity for up to 25 years. During this period, apart from providing beneficial results, it is also useful as a conservation land (Yudono, 2018).

\subsection{Labor}

Article 1 Paragraph 2 of Law Number 13 of 2003 concerning Manpower stated that "Manpower is every individual or person who can work to produce goods and/or services either to fulfill his or her own needs or to fulfill the needs of the society" (Republik Indonesia, 2003).

Workers are individuals who offer skills and abilities to produce goods or services so that companies can obtain benefits and the individual will get a salary or wage according to their expertise (Sumarni \& Soeprianto, 2014).

To find out the labor force and not in labor force requires information, which consists of:

a) The number of people aged 15 to 64 years. This data is called the working-age population.

b) The number of people aged 15 to 64 years but not classified in the labor force, such as students, housekeepers, or others excludes personal activity. This population is called not in the labor force.

Thus, the labor force in a period can be calculated by subtracting the number of the working-age population and not in the labor force. The ratio between the labor force and the working-age population in percentage is called the labor force participation rate (Sukirno, 2013).

Demand for labor is related to the number of workers needed by a particular company or agency. Usually, the demand for labor is influenced by changes in wage levels and changes in other factors that affect production demand, including the ups and downs of market demand for products from the company concerned, reflected in the large volume of production and capital price of goods, namely the value of the machine or tools used in the production process (Sumarsono, 2009).

The definition of demand for labor is a list of various alternative combinations of labor with other available inputs related to salary levels (Anata, 2008). According to Sumarsono (2009), the labor force is everyone willing to work. This definition of labor includes those who work for themselves or their family members who do not receive payment in the form of wages or are willing and able to work, in the sense that they are forced to work because there are no job opportunities. The labor force includes people who are already working, looking for work, and those who do other jobs such as going to school and taking care of the household.

\section{Research Methodology}

This study was conducted in North Maluku Province because the agricultural sector plays an important role and contributes greatly to the economy in North Maluku Province. This study was conducted in January - May 2020. The data collected and processed in this study are data within 5 years. The population in this study was all data on the Farmer Exchange Rate, agricultural production, agricultural land area, and labor in North Maluku Province in 2014-

Copyright $($ 2020. Owned by Author(s), published by Society. This is an open-access article under the CC-BY-NC-SA license. https://doi.org/10.33019/society.v8i2.235 
2018. The data used in this study were secondary data obtained from the Central Agency on Statistics of North Maluku Province in 2020 and other literature related to this study. The test tool used is multiple linear regression analysis, and the analytical tool used is IBM SPSS Statistics 16.0 software.

To obtain the data needed in conducting this study, data collection methods are conducted from literature, books, and journals, which are closely related to the issues studied and also collect data from agencies related to this research such as the Central Agency on Statistics of North Maluku Province and other related agencies.

Several statistical analysis techniques can be used to analyze data. The purpose of this analysis is to obtain relevant information contained in the data and use the results to solve issues. To achieve the objectives in this study used multiple linear regression analysis (Ghozali, 2016).

Multiple linear regression analysis was used to examine the effect of production, selling price, and land area on the exchange rate of farmers in North Maluku Province. Before doing linear regression analysis, first perform a classic assumption test to ensure that the regression model to be used does not experience problems of normality, multicollinearity, and heteroscedasticity. If there are no problems, then the analysis model is suitable.

Multiple linear regression method was used to analyze the effect of independent variables on the dependent variable. Multiple regression analysis is intended to examine the effect of several independent variables on one dependent variable. To determine the effect of production on the exchange rate of farmers, it was analyzed using the multiple linear regression equation models. The regression equation is as follows:

$$
\text { Yit }=a+\beta 1 X 1 i t+\beta 2 X 2 i t+\beta 3 X 3 i t+e
$$

Where:

$\begin{array}{ll}\mathrm{Y} & =\text { Farmer Exchange Rate (percentage) } \\ \text { it } & =\text { Time Period (2014-2018) } \\ \mathrm{a} & =\text { Constant } \\ \beta 1, \beta 2, \beta 3 & =\text { Regression Coefficient } \\ \mathrm{X} 1 & =\text { Production (Tons) } \\ \mathrm{X} 2 & =\text { Land Area (Hectares) } \\ \mathrm{X} 3 & =\text { Labor (People) } \\ \mathrm{e} & =\text { Standard Error }\end{array}$

Farmer Exchange Rate (Y): Reference to measure farmer welfare. In this study, the data used was the Farmer Exchange Rate of the smallholder plantation subsector in North Maluku Province in 2014-2018. The unit used to measure Farmer Exchange Rate is average or percentage. Production (X1): The process of converting inputs into other goods or services of higher value. The data used was the production of smallholder plantations crops in North Maluku Province in 2014-2018. The unit in this variable is the amount of production (in tons). Land Area (X2): The data used was the area of smallholder plantations in North Maluku Province in 2014-2018. The unit in the variable land area in hectares. Labor (X3): The data used was the number of workers in North Maluku Province in 2014-2018. The unit in the labor variable is the number of people employed (people).

Copyright (C) 2020. Owned by Author(s), published by Society. This is an open-access article under the CC-BY-NC-SA license. https://doi.org/10.33019/society.v8i2.235 
This study used multiple linear regression models and the analytical tool used was the IBM SPSS Statistics 16.0 software, and must first pass the classical assumption test, which consists of the normality test, multicollinearity test, heteroscedasticity test, and autocorrelation test to meet the assumptions requirements in regression. The classical assumption test aims to test and determine the feasibility of the regression model used in the study. Another objective is to ensure that the regression model used has data that is normally distributed and free from multicollinearity and heteroscedasticity (Ghozali, 2016).

\section{Results and Discussion}

\subsection{Results}

The regression model testing used in this study will determine the results of analysis related to the effect of production, land area, and labor on the Farmer Exchange Rate of smallholder plantation crops in North Maluku Province through a quantitative approach. But before testing the regression model it is necessary to test the classic assumptions first for the expected regression model to be a good and efficient regression model in the sense of the accuracy of the model used.

\subsubsection{Multicollinearity Test}

Multicollinearity test aims to test whether in the regression model there is a correlation between the independent variables. A good regression model should not correlate with independent variables; if independent variables are correlated then those variables are not orthogonal. An orthogonal variable is an independent variable with a correlation value between independent variables $=0$. Multicollinearity can be seen by comparing correlation coefficients between independent variables (Ghozali, 2016), if the correlation between two variables is greater than 0.8 then this indicates the presence of multicollinearity. Data processing results using IBM SPSS Statistics 16.0 software for multicollinearity tests are as follows:

\section{Table 4. Multicollinearity Test}

\begin{tabular}{|ccc|}
\hline Constant & Tolerance & VIF \\
\hline X1 & 0.345 & 2.898 \\
\hline $\mathbf{X} 2$ & 0.268 & 3.729 \\
\hline $\mathbf{X 3}$ & 0.521 & 1.918 \\
\hline
\end{tabular}

Source: Data processing results using IBM SPSS Statistics 16.0 software (2020)

From the calculation results in Table 4 , the VIF value obtained from the variables $\mathrm{X} 1$ (production), X2 (land area), and X3 (labor), exceeds the value of 1 and is less than 10 which consists of 2,898 (production), 3,729 (land area) and 1,918 (labor). While the tolerance value (TOL) of the three variables is greater than 0.1 , which consists of 0.345 (production), 0.268 (land area), and 0.521 (labor). Thus it can be concluded that the regression does not have multicollinearity problems in this test.

\subsubsection{Autocorrelation Test}

The autocorrelation test aims to test whether in the regression model there is a correlation between confounding variables (residuals) in period $t$ with errors in period $t-1$ (before). The

Copyright (C) 2020. Owned by Author(s), published by Society. This is an open-access article under the CC-BY-NC-SA license. https://doi.org/10.33019/society.v8i2.235 
autocorrelation test is seen from the Durbin Watson statistic. The results of data processing are shown in the table as follows:

Table 5. Autocorrelation Test

\begin{tabular}{|c|c|c|c|}
\hline DU & DW & $4-\mathrm{DU}$ & Information \\
\hline 2,286 & 2,766 & $\mathbf{1 , 7 1 4}$ & No autocorrelation \\
\hline
\end{tabular}

Source: Data processing results using IBM SPSS Statistics 16.0 software (2020)

From the data above, it can be seen that Durbin Watson's value is 2.766 . DL and DU values are obtained by looking at the Durbin Watson table with $\mathrm{n}=5$ and $\mathrm{K}=3$. The DL values are 0.367 and the DU values are 2.286 and less than $4-2.286$ (DU <DW $\leq 4-\mathrm{DU}$ ). It can be concluded that there is no positive or negative autocorrelation or it can be concluded that there is no autocorrelation.

\subsubsection{Heteroscedasticity Test}

From the results of the analysis using IBM SPSS Statistics 16.0 software, it can be seen that the dots spread randomly either above or below zero on the Y-axis and do not form a specific pattern or trend on the plot diagram so that heteroscedasticity is not identified and the regression model is very suitable to be used to measure the Farmer Exchange Rate of smallholder plantation crops. It can be concluded overall that the regression model meets the requirements of the classic assumption test in the form of logarithms. To find out, it can be seen through the scatter table as follows:

\section{Dependent Variable: Farmer Exchange Rate}

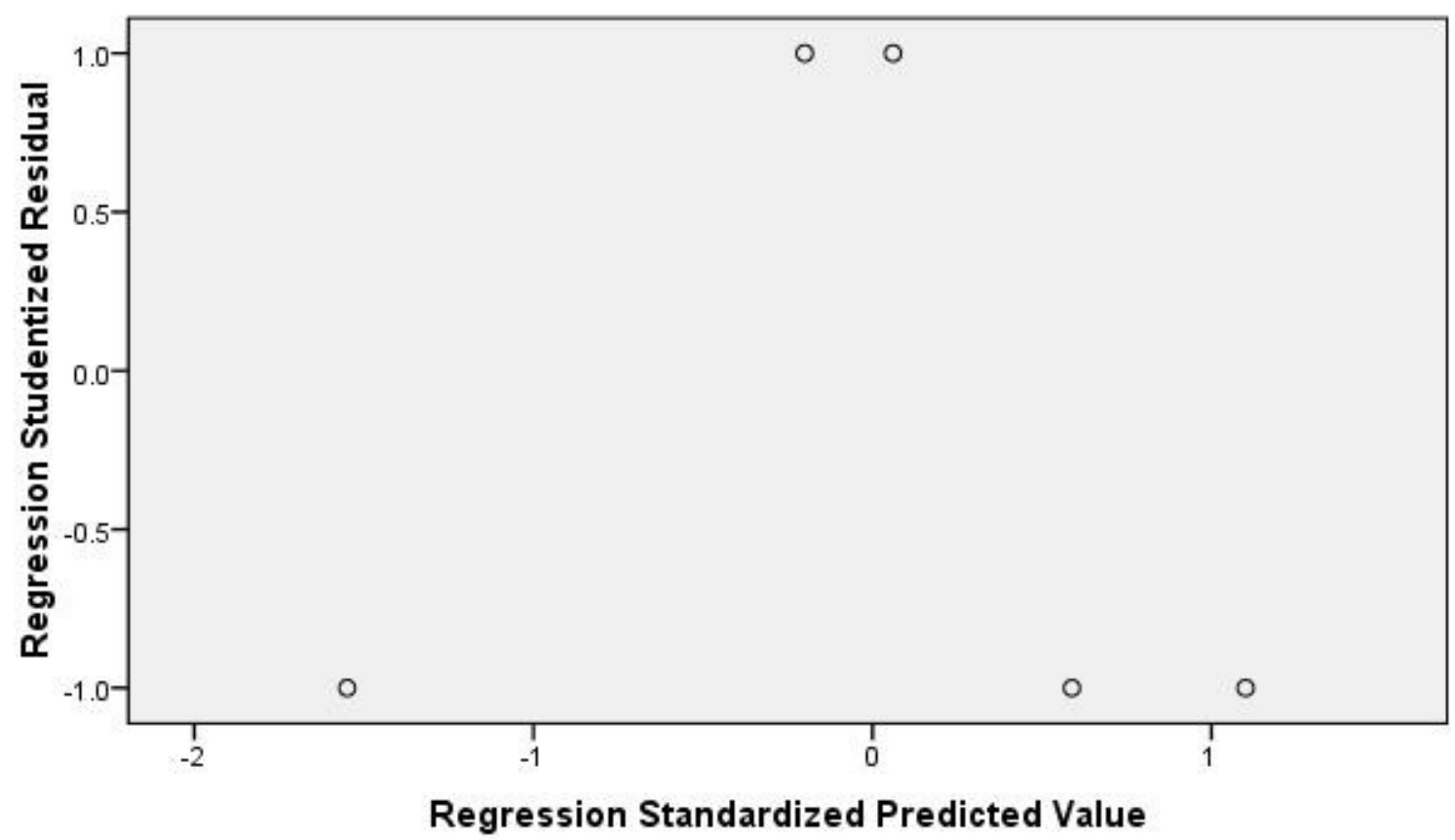

Figure 5. Scatterplot

Source: Data processing results using IBM SPSS Statistics 16.0 software (2020)

Copyright (C) 2020. Owned by Author(s), published by Society. This is an open-access article under the CC-BY-NC-SA license. https://doi.org/10.33019/society.v8i2.235 


\subsubsection{Normality Test}

The test aims to determine the distribution of data on the variables to be used in this study. Data that is good and suitable for use in this study are data that are normally distributed.

Dependent Variable: Farmer Exchange Rate

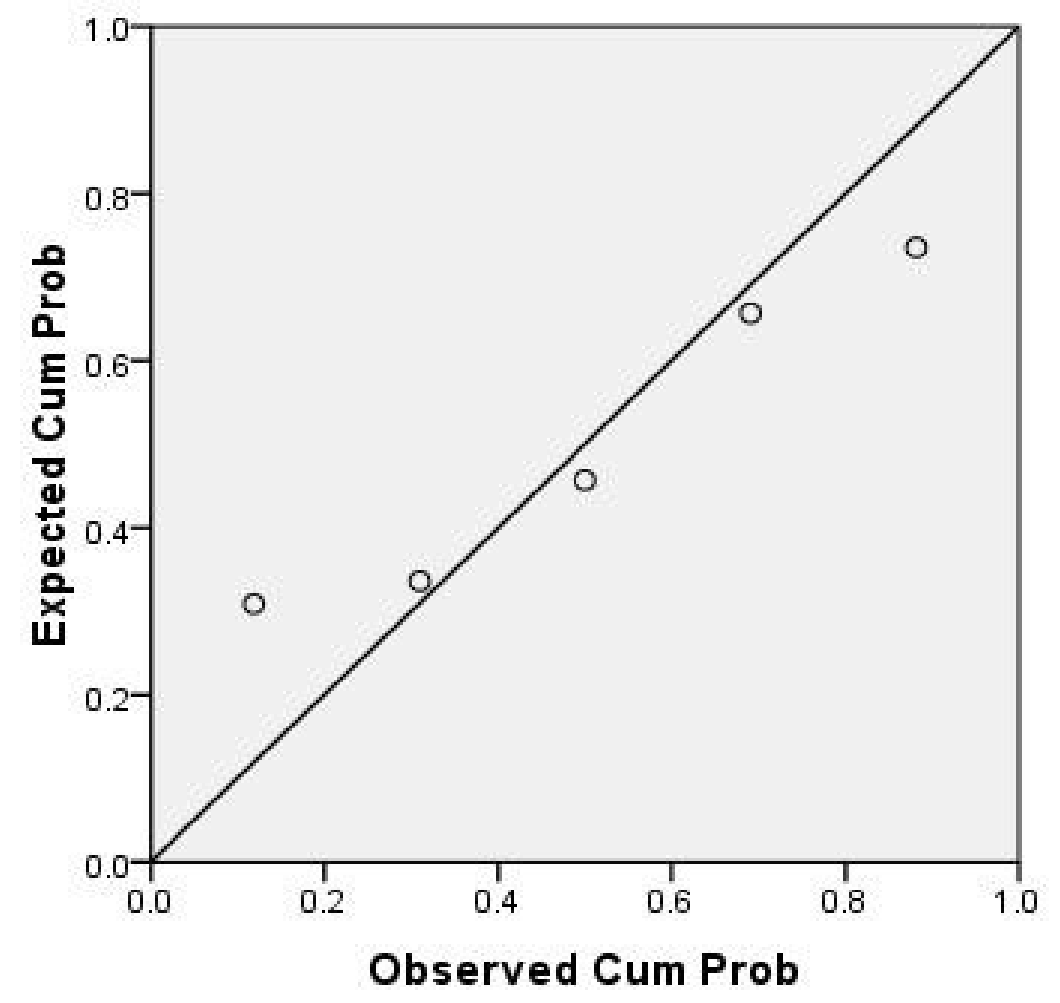

Figure 6. Normal P-P Plot of Regression Standardized Residual Source: Data processing results using IBM SPSS Statistics 16.0 software (2020)

Test sample normality test can be seen in Figure 6 above, the linearity of the relationship and variance similarity can plot between the standardized residual value (ZRESID) and the predicted value (SPRED). The regression relationship is linear and its variance can be seen in the Normal Probability Plot or abbreviated as P-P Plot. Based on Figure 6, it shows that the points are still around the linear line so it can be concluded that the data is normally distributed.

\subsubsection{Coefficient of Determination $\left(R^{2}\right)$}

The coefficient of determination $\left(\mathrm{R}^{2}\right)$ is used to test the goodness of fit of the regression model which can be seen from the $\mathrm{R}$ square value. To determine the level of development of the Farmer Exchange Rate in the smallholder plantation subsector in North Maluku Province which is caused by several factors including production (X1), land area (X2), and labor (X3) which can be seen from the coefficient of determination. From the calculation result, the value of $\mathrm{R}$ square is 1,000 . This means that $100 \%$ of the Farmer Exchange Rate in the smallholder plantation subsector in North Maluku Province can be explained by the three variables above, while the remaining $0 \%$ is explained by other variables not examined in this study. 
Analysis of Macroeconomic Indicators on the Farmer Exchange Rate of North Maluku Province: A Case Study of Smallholder Plantation Subsector

\subsubsection{Simultaneous Test (Test F)}

Table 6. Statistical Results of the F Test

Analysis of Variance (ANOVA)

\begin{tabular}{|c|c|c|c|c|c|}
\hline Model & Sum of Square & DF & Mean Square & $\mathbf{F}$ & Sig. \\
\hline Regression & .001 & 3 & .000 & $8.646 \mathrm{E} 3$ & \\
\hline Residual & .000 & 1 & .000 & & \\
\hline Total & .001 & 4 & & & \\
\hline
\end{tabular}

Source: Data processing results using IBM SPSS Statistics 16.0 software (2020)

In multiple linear regression tests using IBM SPSS Statistics 16.0 software, it shows that the significance value of the F-count data processing results is 0.008 and the F-table value is 0.05 which is significant on the F-count < F-table. So in testing the independent variables (production, land area, and labor) while the dependent variable (Farmer Exchange Rate of smallholder plantation crops) it can be concluded that simultaneously, the variables of production, land area, and labor have a positive and significant effect on Farmer Exchange Rate of smallholder plantation crops in North Maluku Province.

\subsubsection{Partial T-Test}

Table 7. Statistical Results of the T-Test Coefficients

\begin{tabular}{|cccccc|}
\hline Model & $\begin{array}{c}\text { Unstandardized Coefficients } \\
\text { B }\end{array}$ & $\begin{array}{c}\text { Standardized } \\
\text { Coefficients }\end{array}$ & Trror & Sig. \\
\hline (Constant) & -1.005 & .052 & & -19.230 & 0.033 \\
\hline $\mathbf{X 1}$ & -.259 & .020 & -.139 & -13.126 & 0.048 \\
\hline $\mathbf{X} 2$ & 1.582 & .019 & .999 & 83.345 & 0.008 \\
\hline X3 & -.131 & .007 & -.150 & -17.486 & 0.036 \\
\hline
\end{tabular}

Dependent Variables: Production, Land Area, and Labor

Source: Data processing results using IBM SPSS Statistics 16.0 software (2020)

In multiple linear regression test using IBM SPSS Statistics 16.0 software, based on Table 7, the production variable was -0.259 , the land area was 1.582 , labor was -0.131 . The variable that can increase the Exchange Rate of smallholder plantation crops in North Maluku Province is the land area (X2), while production (X1) and labor (X3) cause a decrease in the Exchange Rate of smallholder plantation crops.

From the results of a partial statistical test with a critical value at $\mathrm{df}=\mathrm{nk}-1$ where $(5-3-1=$ 1 ). Then at the level of significance at the degree of confidence of $5 \%$ or 0.05 . From the regression results, the $\mathrm{T}$ value of production was -13.126 , the land area was 83.345 , and labor was -17.486 . While the T-table formula is as follows: $(\mathrm{a} / 2 ; \mathrm{nk}-1)=(0.05 / 2 ; 5-3-1)=(0.025 ; 1)=$ 12.71. The $\mathrm{T}$-table value was 12.71 , so in the $\mathrm{T}$ statistical test where $\mathrm{T}$-count $>\mathrm{T}$-table.

Based on the results of the partial T-Test above, it shows that the variable that has a positive effect was the land area (X2), which means that the wider land area increases the Farmer Exchange Rate of smallholder plantation crops, while production (X1) and labor (X2)

Copyright (C) 2020. Owned by Author(s), published by Society. This is an open-access article under the CC-BY-NC-SA license. https://doi.org/10.33019/society.v8i2.235 
have a negative effect which means increasing production and labor, so the Farmer Exchange Rate of smallholder plantation crops decreases.

While the probability value at the production significance level was $0.048 \%$, the land area was $0.008 \%$, and labor was $0.036 \%$. So by comparing the significance value at the degree of confidence of $5 \%$ or 0.05 , the variables of land area and labor have a smaller value at the degree of confidence of $5 \%$ or 0.05 . So it can be concluded that individually, the variables of production, land area, and labor have a positive and negative effect and have a significant impact on the Farmer Exchange Rate of smallholder plantation crops in North Maluku Province.

\subsection{Discussion}

\subsubsection{The Effect of Production on Farmer Exchange Rate of Smallholder Plantation Crops}

It is hoped that smallholder plantation crops can directly improve farmer welfare because most of the population in North Maluku Province works in the agricultural sector. However, based on the theory of the law of supply, when production increases, the price of goods will decrease. This will have a direct impact on farmers. Expenses are higher than income. Therefore, the government must be careful in making policies to increase production; several aspects must be considered.

According to Dumairy (2018), efforts to increase plantation production are mainly through increasing land productivity and increasing processing efficiency. The main target is to increase the production of smallholder plantations considering that the productivity per hectare and quality of production is still low, while the majority of plantation products come from smallholder plantations. To support the increase in smallholder production, Development Service (Public Service Unit) was formed. These units guide agronomic engineering, assist in the financing, marketing, and development of processing facilities.

Based on Table 7, the significance value of the production variable is smaller than the value of standard error, meaning that $\mathrm{H} 0$ was rejected and $\mathrm{H} 1$ was accepted. So from the results of the T-Test, it can be concluded that individually or partially production has a negative and significant effect on the Farmer Exchange Rate of smallholder plantation crops in North Maluku Province.

This is because production has shown improved development but production still has a negative impact or it can be said that the more production will have an impact on decreasing the Exchange Rate of smallholder plantation crops and can also be interpreted as a decrease in the farmer welfare. This can be caused by the market that is unable to accommodate agricultural production or also a lack of industry that manages the agricultural products of smallholders. Local governments must pay more attention to policies that have a direct impact on agricultural production and improve infrastructure in accommodating agricultural products from farmers with the right policies in agriculture. It is hoped that in the future, production will have a positive impact on the Exchange Rate of smallholder plantation crops.

This study is in line with the research of Nirmala et al, (2016), which stated that the selling products did not have a significant effect on the Farmer Exchange Rate. Production, land area, and pesticides do not have a significant effect on Farmer Exchange Rate. This is because the wider the land area, the higher the expenses for production factors.

Copyright $($ 2020. Owned by Author(s), published by Society. This is an open-access article under the CC-BY-NC-SA license. https://doi.org/10.33019/society.v8i2.235 


\subsubsection{The Effect of Land Area on the Farmer Exchange Rate of Smallholder Plantation Crops}

The production of several plantation crops has increased quite significantly; the increase in production is mainly due to the increase in productive areas as a result of replanting and expansion, as well as rehabilitation and intensification efforts (Dumairy, 2018). It can be concluded that the land area will have an impact on farmer welfare by increasing production and land potential that has not been utilized optimally due to inadequate infrastructure.

Based on Table 7, this variable shows a significant number. It means that H1 was rejected and $\mathrm{H} 0$ was accepted. Individually or partially, the land area has a positive and significant effect on the Farmer Exchange Rate of smallholder plantation crops in North Maluku Province. The wider the land used, the more the Farmer Exchange Rate will also increase. This is because people do not have to spend a lot of money to manage agricultural land. Local governments must make policies that make it easier for people to manage the agricultural land which will also have a direct impact on the Farmer Exchange Rate and the welfare of people who work in the smallholder plantation crops in North Maluku Province.

This study is in line with the research of Faridah \& Syechalad (2016) which stated that the factor of land area has a positive and significant effect on the Farmer Exchange Rate in the subsector of food crops in Aceh.

\subsubsection{The Effect of Labor on the Farmer Exchange Rate of Smallholder Plantation Crops}

Based on Table 7, this variable shows a significant number. It means that H0 was rejected and H1 was accepted. Individually or partially, the labor has a negative and significant effect on the Farmer Exchange Rate of smallholder plantation crops in North Maluku Province.

This indicates that there is a lack of labor development, and it should be noted that labor has a negative effect on the Farmer Exchange Rate of smallholder plantation crops. This is due to the low quality or ability of the labor. The government must take policies in developing the quality of the labor, for example by developing jobs training center, providing scholarships to outstanding students to improve their quality or abilities, and developing agricultural research in North Maluku Province.

\section{Conclusion}

The variable of production did not affect the Farmer Exchange Rate of smallholder plantation crops in North Maluku Province. It means that the increase in this variable will reduce the Farmer Exchange Rate, it can be said that it will also reduce farmer welfare. The variable of land area affects the Farmer Exchange Rate of smallholder plantation crops in North Maluku Province. It means that the increase in this variable will increase the Farmer Exchange Rate, it can be said that it will also increase the farmer welfare. The variable of labor did not affect the Farmer Exchange Rate of smallholder plantation crops in North Maluku Province. It means that the increase in this variable will reduce the Farmer Exchange Rate, it can be said that it will also reduce farmer welfare.

Simultaneously, the independent variables (production, land area, and labor) have a positive and significant effect on the dependent variable (Exchange Rate of smallholder plantation crops in North Maluku Province). This means that these three variables affect the fluctuation of the Farmer Exchange Rate. The government must pay attention to these three variables to have a positive impact on the Farmer Exchange Rate in North Maluku Province, which in turn will improve farmer welfare.

Copyright (C) 2020. Owned by Author(s), published by Society. This is an open-access article under the CC-BY-NC-SA license. https://doi.org/10.33019/society.v8i2.235 
Analysis of Macroeconomic Indicators on the Farmer Exchange Rate of North Maluku Province: A Case Study of Smallholder Plantation Subsector

\section{Acknowledgment}

The author is grateful to express gratitude to all of those who have had the pleasure to work during this research conducted.

\section{Declaration of Conflicting Interests}

The author has declared no potential conflicts of interest concerning the research, authorship, and/or publication of this article.

\section{References}

Akbar, T., Fauzi, M., \& Fajeri, H. (2019). Affecting Factors Farmer Exchange Rate (NTP) of Food Crops South Kalimantan Province. IOSR Journal of Agriculture and Veterinary Science, 12(7), 83-91. Retrieved from http://www.iosrjournals.org/iosr-javs/papers/Vol12issue7/Series-1/L1207018391.pdf

Amelia, D. (2017). Pengaruh Investasi dan Tenaga Kerja Terhadap Produksi Subsektor Perkebunan di Sumatera Barat. Majalah Ilmiah UPI YPTK, 24(1), 121-128. Retrieved from http://lppm.upiyptk.ac.id/majalahilmiah/index.php/majalahilmiah/article/view/74

Anata, A. (2008). Labor Absorption Problems, Prospects and Economic Problems in Indonesia. Jakarta, Indonesia: Sinar Harapan.

Arsyad, S. (1989). Konservasi Tanah dan Air. Bogor, Indonesia: IPB Press.

Arsyad, L. (2010). Ekonomi Pembangunan (5th ed.). Yogyakarta, Indonesia: STIM YPKN.

Badan Pusat Statistik Provinsi Maluku Utara. (2015a). Maluku Utara dalam Angka 2015 (1102001.82).

Retrieved from https:/ / malut.bps.go.id/publication/2016/01/14/580d8f6ccf1cfff4e5ee22fd/malukuutara-dalam-angka-2015.html

Badan Pusat Statistik Provinsi Maluku Utara. (2015b). Statistik Nilai Tukar Petani Provinsi Maluku Utara 2014.

Retrieved from https:/ / malut.bps.go.id/publication/2015/05/29/c8f60ebd9d3566f74527eee5/statistiknilai-tukar-petani-provinsi-maluku-utara-2014.html

Badan Pusat Statistik Provinsi Maluku Utara. (2016). Statistik Nilai Tukar Petani Provinsi Maluku Utara 2016.

Retrieved from https:/ / malut.bps.go.id/publication/2017/05/08/a5e5dcf8938a28c501337507/statistiknilai-tukar-petani-provinsi-maluku-utara-2016.html

Badan Pusat Statistik Provinsi Maluku Utara. (2018). Statistik Nilai Tukar Petani Provinsi Maluku Utara 2018.

Retrieved from https:/ / malut.bps.go.id/publication/2019/05/09/7e1ce5981cbe08e6a1ca41b7/statistiknilai-tukar-petani-provinsi-maluku-utara-2018.html

Badan Pusat Statistik. (2019, May). Keadaan Ketenagakerjaan Indonesia Februari 2019 (No. 41/05/Th. XXII, $06 \quad$ Mei 2019). Retrieved from https://www.bps.go.id/website/materi_ind/materiBrsInd-20190506113732.pdf

Badan Pusat Statistik Provinsi Maluku Utara. (2019, October). Indikator Ekonomi Provinsi Maluku Utara 2018.

Retrieved from https:/ / malut.bps.go.id/publication/2019/10/29/6a4529d39b7a69aae743d99e/indikatorekonomi-provinsi-maluku-utara-2018.html

Copyright (C) 2020. Owned by Author(s), published by Society. This is an open-access article under the CC-BY-NC-SA license. https://doi.org/10.33019/society.v8i2.235 
Badan Pusat Statistik Provinsi Maluku Utara. (2020). Provinsi Maluku Utara dalam Angka 2020. Retrieved from https://malut.bps.go.id/publication/2020/04/27/0c2aa8307ae047d3281a3aee/provinsimaluku-utara-dalam-angka-2020.html

Dua, M. (2008). Filsafat Ekonomi: Upaya Mencari Kesejahteraan Bersama. Yogyakarta, Indonesia: Kanisius.

Dumairy. (2018). Perekonomian Indonesia. Jakarta, Indonesia: Penerbit Erlangga.

Faridah, N., \& Syechalad, M. N. (2016). Analisis faktor-faktor yang mempengaruhi nilai tukar petani sub sektor tanaman pangan padi di Aceh. Jurnal Ilmiah Mahasiswa Ekonomi Pembangunan, 1(1), 169-176. Retrieved from http://www.jim.unsyiah.ac.id/EKP/article/view/689

Ghozali, I. (2016). Aplikasi Analisis Multivariete dengan Program IBM SPSS 23. Semarang, Indonesia: Badan Penerbit Universitas Diponegoro.

Ginting, M. S., Ginting, R., \& Lubis, S. N. (2013). Faktor-Faktor Yang Mempengaruhi Nilai Tukar Petani Ubi Kayu (Studi Kasus: Desa Tadukan Raga, Kecamatan STM Hilir, Kabupaten Deli Serdang, Provinsi Sumatera Utara). Journal of Agriculture and Agribusiness Socioeconomics, $3(3)$. Retrieved from https://jurnal.usu.ac.id/index.php/ceress/article/view/8118

Istiana, F. A. (2018). Analisis Faktor-Faktor yang Mempengaruhi Nilai Tukar Petani di Indonesia Tahun 2013-2017 (Thesis). Universitas Islam Indonesia. Retrieved from https://dspace.uii.ac.id/handle/123456789/13599

Manulang, S. H. (2010). Pokok-Pokok Hukum Ketenagakerjaan Di Indonesia. Jakarta, Indonesia: Rineka Cipta.

Nirmala, A. R., Hanani, N., \& Muhaimin, A. W. (2016). Analisis faktor faktor yang mempengaruhi nilai tukar petani tanaman pangan di Kabupaten Jombang. Habitat, 27(2), 66-71. https:/ / doi.org/10.21776/ub.habitat.2016.027.2.8

Republik Indonesia. (2003). Undang-Undang Republik Indonesia Nomor 13 Tahun 2003 Tentang Ketenagakerjaan. Lembaran Negara Republik Indonesia Tahun 2003 Nomor 39.

Retrieved from https://jdih.kemnaker.go.id/katalog-27-Undang-undang.html

Retnandari, N. D. (2014). Pengantar Ilmu Ekonomi Dalam Kebijakan Publik. Yogyakarta, Indonesia: Pustaka Pelajar.

Riyadh, M. I. (2015). Analisis Nilai Tukar Petani Komoditas Tanaman Pangan di Sumatera Utara. Jurnal Ekonomi \& Kebijakan Publik, 6(1), 17-32. Retrieved from http://jurnal.dpr.go.id/index.php/ekp/article/view/161

Sukirno, S. (2013). Mikro Ekonomi Teori Pengantar. Jakarta, Indonesia: PT Raja Grafindo Persada.

Sumarni, M., \& Soeprianto, J. (2014). Pengantar Bisnis (Dasar-dasar Ekonomi Perusahaan). Yogyakarta, Indonesia: Liberty.

Sumarsono, S. (2009). Teori Dan Kebijakan Publik Ekonomi Sumber Daya Manusia. Yogyakarta, Indonesia: Graha Ilmu.

Tarigan, R. (2015). Ekonomi Regional. Jakarta, Indonesia: PT Bumi Aksara.

Winardi. (1992). Ekonomi Mikro: Aspek-Aspek Pengusaha Badan Usaha Perusahaan. Bandung, Indonesia: Mandar Maju.

Yudono, P. (2018). Pengantar Ilmu Pertanian. Yogyakarta, Indonesia: Gadjah Mada University Press.

Copyright (C) 2020. Owned by Author(s), published by Society. This is an open-access article under the CC-BY-NC-SA license. https://doi.org/10.33019/society.v8i2.235 
Analysis of Macroeconomic Indicators on the Farmer Exchange Rate of North Maluku Province: A Case Study of Smallholder Plantation Subsector

\section{About the Author}

Prince Charles Heston Runtunuwu, obtained his Doctoral degree from Universitas Airlangga, Surabaya, Indonesia, in 2018. The author is an Assistant Professor at the Department of Development Economics, Faculty of Economics and Business, Universitas Khairun, Indonesia. E-Mail: princecharles@unkhair.ac.id 